\title{
Thioredoxin as a Modulator of Glucose-6-phosphate Dehydrogenase in a $\mathrm{N}_{2}$-Fixing Cyanobacterium
}

\author{
By J. D. COSSAR, P. ROWELL*AND W. D. P. STEWART \\ ARC Research Group on Cyanobacteria and Department of Biological Sciences, \\ University of Dundee, Dundee DDI $4 H N, U K$
}

(Received 22 August 1983)

\begin{abstract}
Glucose-6-phosphate dehydrogenase (G6PDH) is a key enzyme involved in fixed carbon dissimilation in photosynthetic micro-organisms; in heterocystous cyanobacteria it may also be implicated in the supply of reductant to nitrogenase. In crude cell-free extracts of the $\mathrm{N}_{2}$-fixing cyanobacterium Anabaena variabilis G6PDH activity was reversibly deactivated by the thiol agent dithiothreitol in the presence of a low molecular weight protein $(12000 \mathrm{~mol}$. wt). Glucose 6-phosphate reversed deactivation when added at high concentration, or prevented deactivation if added with the thiol. NADP ${ }^{+}$, which, like glucose 6-phosphate, is a G6PDH substrate, also deactivated the enzyme; deactivation was reversed or prevented by adding glucose 6-phosphate or glutamine. Purified thioredoxin from Anabaena cylindrica, at very low concentrations ( $2 \mathrm{nM}$ ), deactivated purified G6PDH in a manner identical to that observed when crude extracts were used in the presence of dithiothreitol. Glutathione did not affect the enzyme.
\end{abstract}

\section{INTRODUCTION}

Cyanobacteria are photosynthetic prokaryotes which use water as source of reductant and fix $\mathrm{CO}_{2}$ via the Calvin cycle with ribulose-1,5-bisphosphate carboxylase serving as the key carboxylating enzyme, as in higher plants. Fixed carbon dissimilation is mainly via the oxidative pentose phosphate pathway (Pelroy \& Bassham, 1972) with glucose-6-phosphate dehydrogenase (G6PDH) being the first enzyme involved in hexose dissimilation via this route (see Stewart, 1980; Smith, 1982). There is also evidence that it may be involved in electron transfer to nitrogenase in cyanobacteria providing $\mathrm{NADPH}$, from the dissimilation of fixed carbon, which transfers electrons to ferredoxin via ferredoxin-NADP ${ }^{+}$oxidoreductase and hence to nitrogenase (Apte et al., 1978). This enzyme occupies a key branch point of carbon metabolism in cyanobacteria and thus its regulation is of particular importance. NADPH (Pelroy et al., 1976; Apte et al., 1978), ATP (Grossman \& McGowan, 1975) and light (Duggan \& Anderson, 1975) have all been shown to regulate G6PDH and there is evidence that it may be redox-modulated (Czeke et al., 1981). However, the overall regulation of the enzyme is unclear (Schaeffer \& Stanier, 1978). Here we provide evidence that thioredoxin may be involved in the modulation of the G6PDH of heterocystous cyanobacteria and consider ways in which this may be of importance.

\section{METHODS}

Organism and culture conditions. Anabaena variabilis Kütz. ATCC 29413 was grown in axenic culture in oneeighth strength Allen \& Arnon's medium (Allen \& Arnon, 1955), without combined nitrogen unless stated otherwise, at $25^{\circ} \mathrm{C}$ and at a photon flux density incident at the surface of the vessel of $70 \mu \mathrm{mol} \mathrm{m}^{-2} \mathrm{~s}^{-1}$, in 101 batch culture or in continuous culture at a dilution rate of $0.03 \mathrm{~h}^{-1}$

Abbreviation: G6PDH, glucose-6-phosphate dehydrogenase. 
Preparation of cell-free extracts. Cultures were harvested by centrifugation using a Sharples continuous centrifuge, resuspended and washed twice in $20 \mathrm{~mm}$-Tris/maleate buffer (pH 6.5). Cells were disrupted by passage three times through a French pressure cell at $110 \mathrm{MPa}$ and cell debris was removed by centrifugation at $10000 \mathrm{~g}$ for $10 \mathrm{~min}$.

Purification of G6PDH. For purification of the enzyme, the cyanobacterium was grown in Allen \& Arnon's medium as above, but supplemented with $5 \mathrm{~mm}$-fructose both to increase biomass and provide cells with enhanced G6PDH activity. Cells (about $30 \mathrm{~g}$ wet weight) were harvested, washed and resuspended in $20 \mathrm{~mm}$-Tris/maleate buffer ( $\mathrm{pH} 6.5$ ) and disrupted by passage through a French pressure cell as above. The cell-free extract was treated with $\left(\mathrm{NH}_{4}\right)_{2} \mathrm{SO}_{4}$ to $35 \%$ saturation for $30 \mathrm{~min}$, and then centrifuged at $35000 \mathrm{~g}$ for $30 \mathrm{~min}$. The resulting supernatant was dialysed against $20 \mathrm{mM}$-Tris/maleate buffer $\left(\mathrm{pH} \mathrm{6.5)}\right.$ to remove $\left(\mathrm{NH}_{4}\right)_{2} \mathrm{SO}_{4}$, then chromatographed on DEAE-cellulose $(27 \times 2 \mathrm{~cm}$ column). The column was eluted with a gradient of 0 to $0.7 \mathrm{M}-\mathrm{KCl}$ in $20 \mathrm{mM}$-Tris/maleate buffer ( $\mathrm{pH} \mathrm{6.5)}$. Fractions showing highest G6PDH activity were pooled, treated with $\left(\mathrm{NH}_{4}\right)_{2} \mathrm{SO}_{4}$ to $80 \%$ saturation for $30 \mathrm{~min}$, and then centrifuged at $35000 \mathrm{~g}$ for $30 \mathrm{~min}$. The resulting precipitate was taken up in a small volume of buffer and dialysed to remove $\left(\mathrm{NH}_{4}\right)_{2} \mathrm{SO}_{4}$. Samples $(2.5 \mathrm{ml})$ were chromatographed on Bio-Gel Al.5 m (105 × $1.8 \mathrm{~cm}$ column). Active fractions were pooled and concentrated by chromatography on DEAE-cellulose $(3 \times 1.1 \mathrm{~cm}$ column); the enzyme was eluted with $0.15 \mathrm{M}-\mathrm{KCl}$ in $20 \mathrm{~mm}$-Tris/maleate buffer (pH 6.5). All operations were carried out at $4{ }^{\circ} \mathrm{C}$.

G6PDH assay (EC 1.1.1.49). Enzyme activity was assayed by following the reduction of NADP ${ }^{+}$at $340 \mathrm{~nm}$. The reaction mixture contained, in addition to enzyme, in a total volume of $3 \mathrm{ml}: 2 \cdot 2 \mu \mathrm{mol} \mathrm{NADP}{ }^{+} ; 15 \mu \mathrm{mol}$ glucose 6-phosphate; $30 \mu \mathrm{mol} \mathrm{MgCl}_{2}$ and $150 \mu \mathrm{mol}$ Tris/maleate buffer ( $\mathrm{pH} \mathrm{6.5)}$.

Protein determinations. The Lowry method was used with bovine serum albumin serving as the standard except for purified enzyme where the turbidimetric method of Mejbaum-Katzenellenboger \& Dobryszycka (1959) was used.

Polyacrylamide gel electrophoresis. This was a modification of the method of Davis (1964). Electrophoresis was carried out using vertical slab gels $(15 \times 15 \mathrm{~cm})$ containing $7 \cdot 5 \%(\mathrm{w} / \mathrm{v})$ acrylamide and $0 \cdot 27 \%(\mathrm{w} / \mathrm{v}) N, N^{\prime}$-methylenebisacrylamide in $0.1 \mathrm{M}$-Tris/glycine buffer ( $\mathrm{pH} 8.8$ ), at a current of $30 \mathrm{~mA}$ for $2 \mathrm{~h}$. For molecular weight estimations, according to Hedrick \& Smith (1968), gels contained 5.5, 6.5, 7.0 or $7.5 \%(\mathrm{w} / \mathrm{v})$ acrylamide and the molecular weight standards used were pepsin (35000), ovalbumin (46000), bovine serum albumin (68000), yeast glucose-6-phosphate dehydrogenase (128000), and ferritin (440000). Gels were stained for protein with $0.025 \%$ $(\mathrm{w} / \mathrm{v})$ Coomassie Brilliant Blue R, 25\% (v/v) propan-2-ol and $10 \%(\mathrm{v} / \mathrm{v})$ acetic acid in water for $18 \mathrm{~h}$, followed by intensification in $0.0025 \%(\mathrm{w} / \mathrm{v})$ Coomassie Brilliant Blue, $10 \%(\mathrm{v} / \mathrm{v})$ propan-2-ol and $10 \%(\mathrm{v} / \mathrm{v})$ acetic acid in water. Destaining was in $16.5 \%(\mathrm{v} / \mathrm{v})$ methanol and $5 \%(\mathrm{v} / \mathrm{v})$ acetic acid in water.

SDS-polyacrylamide gel electrophoresis. This was done using a $10 \%(\mathrm{w} / \mathrm{v})$ acrylamide, $0 \cdot 23 \%(\mathrm{w} / \mathrm{v}) N, N^{\prime}$-methylenebisacrylamide resolving gel $(15 \times 15 \mathrm{~cm})$ and a $5 \%(\mathrm{w} / \mathrm{v})$ acrylamide, $0 \cdot 13 \%(\mathrm{w} / \mathrm{v}) N, N^{\prime}$-methylenebisacrylamide stacking gel, according to the method of Laemmli (1970). Standard proteins used were bovine serum albumin (68000), ovalbumin (46000), pepsin (35000), chymotrypsinogen A (25000), trypsin (23300) and lysozyme (14000). Gels were stained and destained as above.

Isoelectric focusing. This was carried out on horizontal slab gels using an LKB multiphor and an LKB 2103 power supply, a suitable $\mathrm{pH}$ gradient being formed using LKB ampholine ampholytes. Gels were fixed for $1 \mathrm{~h}$ using $11.4 \%(\mathrm{w} / \mathrm{v})$ trichloroacetic acid, $3.4 \%(\mathrm{w} / \mathrm{v})$ sulphosalicylic acid and $30 \%(\mathrm{v} / \mathrm{v})$ methanol in water, stained for protein and destained as above. The $\mathrm{pH}$ gradient was determined using a combined surface electrode (Pye Unicam 403-30-M3).

Thioredoxin. Thioredoxin was purified from Anabaena cylindrica using a method based on that of Wolosiuk et al. (1980). The deactivation of G6PDH and activation of fructose-1,6-bisphosphatase were used to monitor thioredoxin throughout purification. The thioredoxin, which was electrophoretically homogeneous, had a molecular weight of 11800 and an $\mathrm{N}$-terminal amino acid sequence which closely resembled that of other bacterial thioredoxins. Full details of the purification and characterization of this thioredoxin will be published elsewhere.

\section{RESULTS}

\section{G6PDH activity of $\mathrm{N}_{2}$-grown and $\mathrm{NO}_{3}^{-}$-grown Anabaena variabilis}

G6PDH in cell-free extracts $(10000 \mathrm{~g}$ supernatants) of $A$. variabilis, which had been grown photoautotrophically in $\mathrm{N}$-free medium in a continuous culture, had a specific activity $( \pm \mathrm{SE})$ of $57.3 \pm 3.7 \mathrm{nmol} \mathrm{NADP}^{+}$reduced $\min ^{-1}(\mathrm{mg} \text { protein })^{-1}$. When the medium was supplemented with $0.8 \mathrm{mM}^{-\mathrm{NaNO}_{3}}$, the specific activity was $30.8 \pm 4.3 \mathrm{nmol} \mathrm{NADP}{ }^{+}$reduced $\min ^{-1}$ (mg protein $)^{-1}$. The lower activity in extracts of $\mathrm{NO}_{3}^{-}$-grown filaments may have been due to an inhibition of heterocyst production by $\mathrm{NO}_{3}^{-}$since heterocysts show enhanced G6PDH activity compared with vegetative cells (Winkenbach \& Wolk, 1973; Lex \& Carr, 1974; Apte et al., 1978). $\mathrm{N}_{2}$-grown filaments were used in all subsequent experiments. 


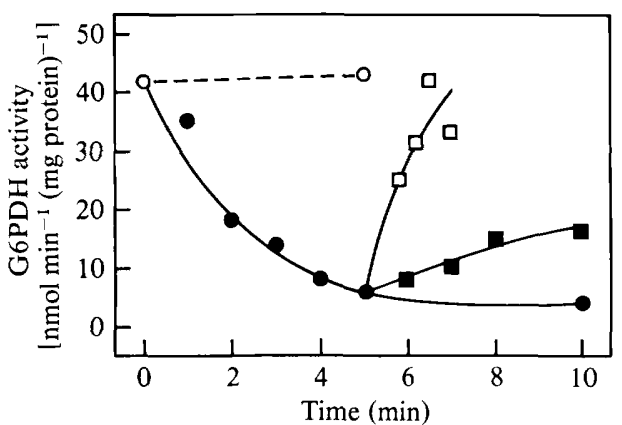

Fig. 1

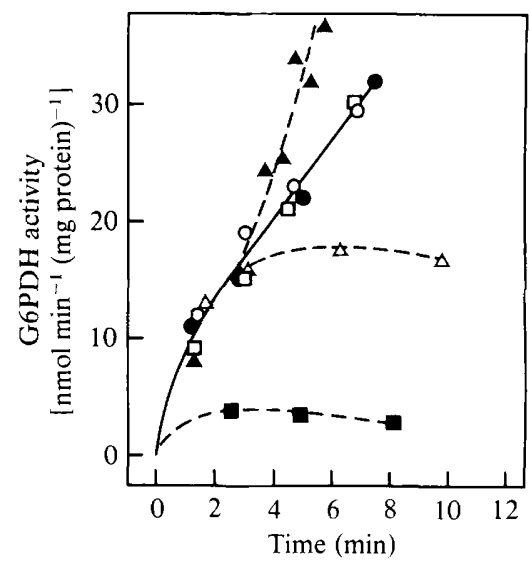

Fig. 2

Fig. 1. Effects of DTT and glucose 6-phosphate on the activity of G6PDH of $A$. variabilis. Cell-free extracts of $A$. variabilis $(220 \mu \mathrm{g}$ protein) were incubated in a volume of $0.2 \mathrm{ml}$ at $\mathrm{pH} 6.8$, without $(O)$ or with (O) 25 mM-DTT. Glucose 6-phosphate was added to a final concentration of $50 \mathrm{~mm}(\square)$ or $5 \mathrm{~mm}$ (a), 5 min after adding DTT. All points are means of at least three replicates with a SE less than $\pm 10 \%$.

Fig. 2. Effects of adding DTT or glutamine during the reactivation by glucose 6-phosphate of G6PDH of $A$. variabilis which had previously been deactivated by incubation with NADP ${ }^{+}$. Cell-free extracts of A. variabilis ( $480 \mu \mathrm{g}$ protein) were preincubated with $70 \mu \mathrm{M}-\mathrm{NADP}^{+}$at $\mathrm{pH} 7.5$ for $2 \mathrm{~min}$ in a volume of $2.95 \mathrm{ml}$ then glucose 6-phosphate was added to $5 \mathrm{~mm}$. Enzyme reactivated in the absence of DTT $(O$, -,$\square$ ); enzyme to which DTT was added to a concentration of $5 \mathrm{~mm}$ at the same time as $(\boldsymbol{\square})$ or $2.5 \mathrm{~min}$ after $(\triangle)$ the addition of glucose 6-phosphate; and enzyme to which glutamine was added to a concentration of $0.5 \mathrm{~mm} 2.5 \mathrm{~min}$ after the addition of glucose 6-phosphate $(\mathbf{\Delta})$.

\section{Effects of dithiothreitol, NADP ${ }^{+}$, glucose 6-phosphate and glutamine on G6PDH activity in cell-free extracts}

When cell-free extracts of $A$. variabilis were incubated with $25 \mathrm{mM}$-dithiothreitol (DTT) at pH 6.5 there was a $90 \%$ reduction in activity within 5 min (Fig. 1). Deactivation proceeded with apparent first order kinetics, a plot of log activity versus time being linear. Incubation of cellfree extracts with $25 \mathrm{mM}$-DTT in the presence of $50 \mu \mathrm{M}$-glucose 6-phosphate or $0.5 \mathrm{~mm}$ glutamine did not result in a significant decrease in activity compared with a control without glucose 6-phosphate or glutamine. On subsequent addition of glucose 6-phosphate to deactivated enzyme, reactivation occurred rapidly at $50 \mathrm{~mm}$-glucose 6-phosphate but only slowly at 5 mm-glucose 6-phosphate (see Fig. 1); at lower concentration reactivation did not occur. Similar effects of DTT and glucose 6-phosphate on G6PDH of Plectonema boryanum have been demonstrated (Raboy et al., 1976).

It has been shown that G6PDH of Anabaena 7120 is deactivated on incubation with NADP ${ }^{+}$ (Schaeffer \& Stanier, 1978). After preincubation of cell-free extracts of $A$. variabilis with $0.7 \mathrm{mM}$ $\mathrm{NADP}^{+}$at $\mathrm{pH} 7.5$ to deactivate the enzyme, activity was restored on adding $5 \mathrm{~mm}$-glucose 6phosphate (Fig. 2). Deactivation was not observed when the enzyme was preincubated with NADP $\bullet$ at $\mathrm{pH} 6 \cdot 5$. Addition of 5 mM-DTT at various times during reactivation prevented any further increase in activity but did not result in significant deactivation of the enzyme. Addition of $0.5 \mathrm{mM}$-glutamine during reactivation markedly increased the rate of activation. Thus in cellfree extracts the substrate glucose 6-phosphate and the amino acid glutamine stabilized the enzyme in the activated state whereas DTT or NADP ${ }^{+}$deactivated it, but only in the absence of glucose 6-phosphate or glutamine.

Involvement of a low molecular weight component in the regulation of A. variabilis G6PDH activity

The deactivation of G6PDH by DTT is in keeping with previous findings for the cyanobacterial enzyme (Duggan \& Anderson, 1975). Fig. 3 shows the effect of $25 \mathrm{~mm}$-DTT on G6PDH preparations where the enzyme had been partially purified by gel filtration on 


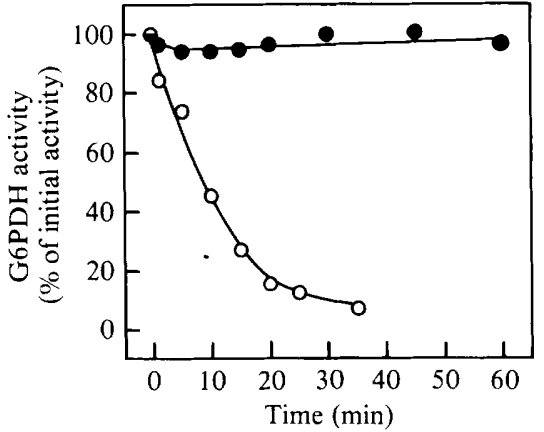

Fig. 3

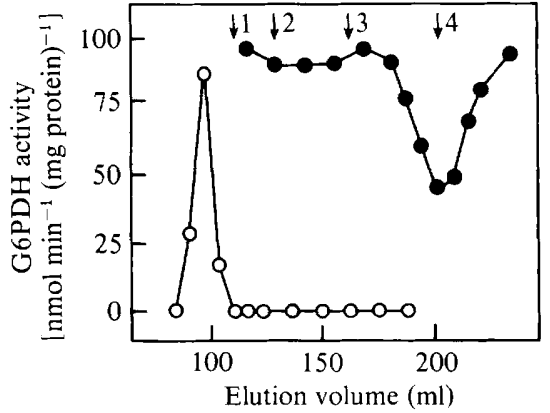

Fig. 4

Fig. 3. Effects of DTT on G6PDH activity in a partially purified cell-free extract of $A$. variabilis before (O) and after ( ) gel filtration of the same preparation on Sephadex G-75 $(140 \times 1.5 \mathrm{~cm}$ column $)$. The cell-free extract was treated with $\left(\mathrm{NH}_{4}\right)_{2} \mathrm{SO}_{4}$ to $30 \%$ saturation for $30 \mathrm{~min}$ and centrifuged at $35000 \mathrm{~g}$ for $30 \mathrm{~min}$. The supernatant was treated with $\left(\mathrm{NH}_{4}\right)_{2} \mathrm{SO}_{4}$ to $80 \%$ saturation for $30 \mathrm{~min}$ and then centrifuged at $35000 \mathrm{~g}$ for $30 \mathrm{~min}$. The resulting pellet was resuspended in a small volume of $50 \mathrm{~mm}$ Tris/maleate buffer ( $\mathrm{pH} \mathrm{6.5)} \mathrm{and} \mathrm{dialysed} \mathrm{against} \mathrm{the} \mathrm{same} \mathrm{buffer} \mathrm{for} 18 \mathrm{~h}$. Enzyme preparations containing 40 to $70 \mu \mathrm{g}$ protein with specific activities of 151 and $267 \mathrm{nmol} \mathrm{NADP}{ }^{+}$reduced min $^{-1}\left(\mathrm{mg}^{2}\right.$ protein $)^{-1}$ (before and after gel filtration respectively) were incubated with $25 \mathrm{~mm}$-DTT at pH 6.5 and $28^{\circ} \mathrm{C}$ for the time indicated, before assay.

Fig. 4. Chromatography of a partially purified (see Fig. 3) cell-free extract (4 mg protein) of $A$. variabilis on a $140 \times 1.5 \mathrm{~cm}$ column of Sephadex G-75. A sample $(0.1 \mathrm{ml})$ of each fraction was assayed for G6PDH activity $(O)$. Samples $(0 \cdot 1 \mathrm{ml})$ of the fraction showing highest activity (G6PDH was eluted in the void volume) were then assayed, following incubation for $15 \mathrm{~min}$ in the presence of $25 \mathrm{mM}$-DTT plus $0.1 \mathrm{ml}$ of a fraction eluting between $120 \mathrm{ml}$ and $240 \mathrm{ml}(\mathrm{O})$. Molecular weight standards used were: bovine serum albumin, 68000 (1); ovalbumin, 46000 (2); chymotrypsinogen, 25700 (3) and cytochrome $c, 12500$ (4).

Sephadex G-75 to remove components of lower molecular weight (proteins $<70000 \mathrm{~mol}$. wt). There was no loss of activity over a $60 \mathrm{~min}$ period whereas, before gel filtration, activity decreased by $90 \%$ within 30 min of adding DTT. The fact that deactivation was slower than that shown in Fig. 1 may be due to the lower concentration of proteins. In any case, a component of the cell-free extract was required to mediate deactivation of G6PDH by DTT. The deactivation of the partially purified enzyme by 25 mM-DTT was restored by preincubating it with samples of the eluate from Sephadex G-75 which would have contained proteins with a molecular weight of approximately 12000 (Fig. 4).

\section{Purification and properties of G6PDH from A. variabilis}

In a previous report of the partial purification of G6PDH from the cyanobacterium Anabaena 7120 (Schaeffer \& Stanier, 1978) sucrose-gradient centrifugation and polyacrylamide gel electrophoresis distinguished three forms with molecular weights of $110000\left(\mathrm{M}_{1}\right), 240000\left(\mathrm{M}_{2}\right)$ and $345000\left(\mathbf{M}_{3}\right)$ : the hypoactive, normal and hyperactive forms, respectively. G6PDH from $A$. variabilis was purified to electrophoretic homogeneity although in many preparations two minor species of greater electrophoretic mobility were also detected (data not shown); the major species was identified as G6PDH by staining for enzyme activity (Igaue et al., 1981). A single major species ( $\mathrm{pI}=4.7$ ) was observed on isoelectric focusing (Fig. 5). Activity was eluted as a single peak from a column of Bio-Gel A1.5 m. The specific activity was approximately $7.5 \mu \mathrm{mol}$ $\mathrm{NADP}^{+}$reduced $\mathrm{min}^{-1}(\mathrm{mg} \text { protein })^{-1}$ which represents a 130 -fold purification of the enzyme; this compares with a 60 -fold purification obtained by Schaeffer \& Stanier (1978). Gel filtration on Bio-Gel A1.5 m and electrophoresis in gels of various polyacrylamide concentrations gave a molecular weight of approximately 250000 . Polyacrylamide gel electrophoresis in the presence of SDS indicated a single type of polypeptide with a molecular weight of 56200 . The purified enzyme thus appears to be a tetramer corresponding to the $\mathbf{M}_{2}$ form (normal state) observed by Schaeffer \& Stanier (1978). 


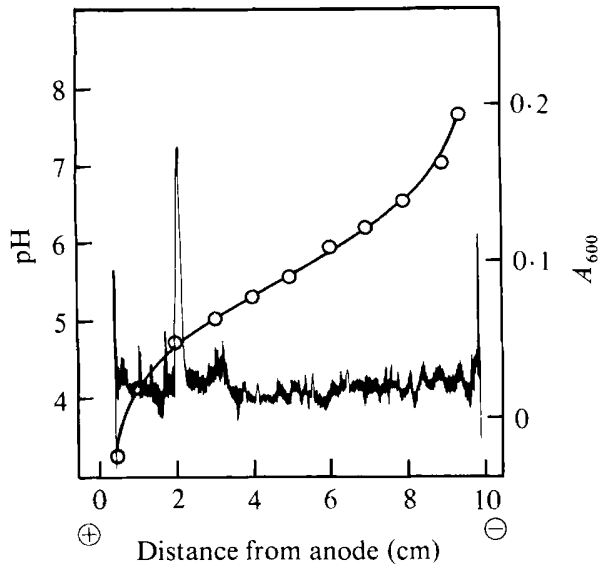

Fig. 5

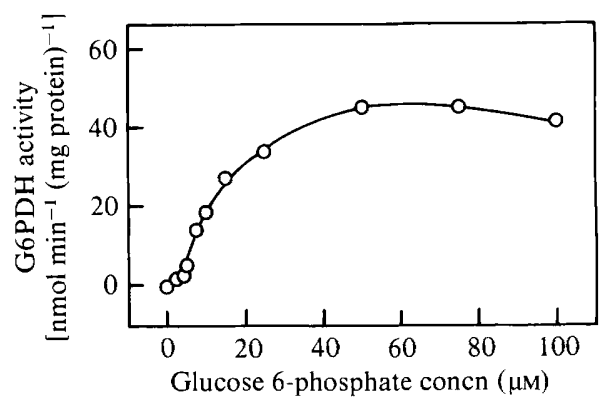

Fig. 6

Fig. 5. Isoelectric focusing of purified G6PDH (6.4 $\mu \mathrm{g}$ protein). $\bigcirc, \mathrm{pH}$.

Fig. 6. Effect of varying the concentration of glucose 6-phosphate on the activity of purified G6PDH.

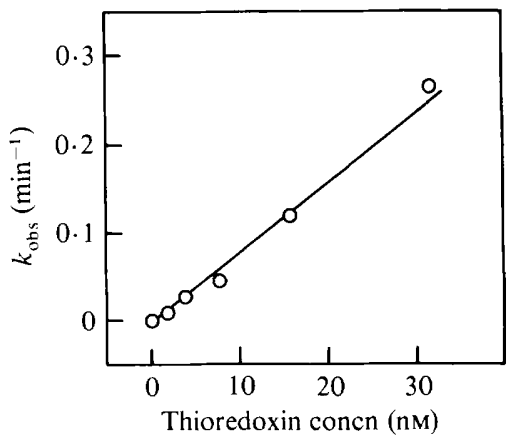

Fig. 7. Effect of varying the thioredoxin concentration on the rate of deactivation of purified G6PDH of $A$. variabilis. Enzyme $(1.6 \mu \mathrm{g})$ was incubated together with $2.5 \mathrm{~mm}$-DTT plus purified thioredoxin from $A$. cylindrica at $\mathrm{pH} 6.5$ and $28^{\circ} \mathrm{C}$. The apparent first order rate constants $\left(k_{\mathrm{obs}}\right)$ were calculated from the plots of $\log$ of activity versus time after DTT addition.

The $K_{\mathrm{m}}$ of the enzyme for NADP ${ }^{+}$was $15 \cdot 5 \mu \mathrm{M}$, similar to that obtained previously for G6PDH from various sources (Levy, 1979). The plot of activity against NADP ${ }^{+}$concentration was hyperbolic, showing typical Michaelis-Menten kinetics. The graph of the effect of glucose 6-phosphate concentration on G6PDH, on the other hand, was sigmoidal (Fig. 6), indicative of positive cooperativity in the binding of glucose 6-phosphate or of the presence of both active and inactive forms of the enzyme. At the $\mathrm{pH}$ used (6.5) G6PDH would be expected to be in the normal (active) state (Schaeffer \& Stanier, 1978).

\section{Effect of thioredoxin on the activity of purified G6PDH}

We have demonstrated the presence in $A$. variabilis of a low molecular weight protein(s) (approximately $12000 \mathrm{~mol}$. wt) which deactivated G6PDH. There is also evidence that G6PDH of higher plant chloroplasts is modulated by the protein thioredoxin (Ashton et al., 1980; Scheibe \& Anderson, 1981). It seemed possible, therefore, that the factor involved in the regulation of G6PDH was thioredoxin or glutaredoxin, both of which have molecular weights of about 12000 (Holmgren, 1976; Tsang, 1981). Our finding that reduced glutathione at concentrations up to $20 \mathrm{~mm}$ (data not shown), unlike DTT, did not deactivate G6PDH suggested that the factor was likely to be thioredoxin rather than glutaredoxin. We therefore examined the effect of various concentrations of purified cyanobacterial thioredoxin on the rate of deactivation of purified G6PDH by DTT in the absence of substrates (Fig. 7). DTT alone did 
not cause deactivation, as noted above for the partially purified enzyme. However, when thioredoxin concentrations as low as $2 \mathrm{nM}$ were used together with DTT $(2.5 \mathrm{mM})$, deactivation of G6PDH occurred with apparent first order kinetics. At thioredoxin concentrations greater than $32 \mathrm{nM}$, the rate at which the reaction proceeded to completion was too rapid to allow its accurate measurement. Reduced glutathione (data not shown) had no effect on G6PDH activity at concentrations up to $20 \mathrm{mM}$ in the presence of thioredoxin. Thus, deactivation of G6PDH from the $\mathrm{N}_{2}$-fixing cyanobacterium $A$. variabilis by a thioredoxin-mediated process clearly occurs.

\section{DISCUSSION}

Glucose-6-phosphate dehydrogenase (G6PDH), both in higher plants (Wildner, 1975; Igaue et al., 1981) and cyanobacteria (Schaeffer \& Stanier, 1978), is a hysteretic enzyme which can exist in an active associated form or in an inactive dissociated form. There is good evidence from work on cyanobacteria that, in vegetative cells, G6PDH activity is light-modulated, with activity being lower in the light than in the dark. Such an inhibition/deactivation in the light has been explained in terms of allosteric regulation by ribulose 1,5-bisphosphate (Pelroy et al., 1972; Schaeffer \& Stanier, 1978), by ATP (Grossman \& McGowan, 1975) and by NADPH (Pelroy et al., 1976; Apte et al., 1978), all of which are generated photosynthetically. The equilibrium between the active and inactive forms of the enzyme can be affected by metabolites such as $\mathrm{NADP}^{+}$, glucose 6-phosphate and glutamine and by physicochemical factors such as $\mathrm{pH}$ (Schaeffer \& Stanier, 1978).

We have shown in this paper that the $A$. variabilis enzyme, like that of Anabaena 7120 (ATCC 27893; Schaeffer \& Stanier, 1978) and $A$. cylindrica (Apte et al., 1978) may be regulated in vitro by $\mathrm{NADP}^{+}$and glucose 6-phosphate. Also important, however, is our finding that in $A$. variabilis G6PDH is regulated by thioredoxin. Thioredoxins are small proteins (mol. wt $\sim 12000$ ) which have been implicated in enzyme activation/deactivation in plants and cyanobacteria (Buchanan et al., 1979); other regulatory proteins are the light effect mediator system (Mohammed \& Anderson, 1981) and ferralterin (Lara et al., 1980; de la Torre et al., 1982). Most attention has been paid to their effects on fructose-1,6-bisphosphatase and other enzymes of the Calvin-Benson cycle. The effect of thioredoxin on G6PDH of higher plants has been reported by Scheibe \& Anderson (1981) and there is a recent report of thioredoxin-mediated deactivation of G6PDH in the unicellular cyanobacterium Anacystis nidulans (Udvardy et al., 1983).

The thioredoxin used in this investigation was from Anabaena cylindrica. This purified thioredoxin, at concentrations as low as $2 \mathrm{nM}$, deactivated purified $A$. variabilis G6PDH indicating a potential regulatory role for this protein in heterocystous $\mathrm{N}_{2}$-fixing cyanobacteria. The deactivation required reduced thioredoxin, which was produced in vitro by adding DTT but, in vivo, reduction probably depends on reduction of thioredoxin by ferredoxin-thioredoxin oxidoreductase (Yee et al., 1981). The precise mechanism of deactivation may involve reduction of an enzyme disulphide, or thioredoxin may catalyse an intramolecular thiol-disulphide exchange involving a cysteine and a disulphide in the enzyme (Anderson et al., 1978).

The involvement of thioredoxin in G6PDH modulation has important implications in $\mathrm{N}_{2}$ fixing cyanobacteria and adds a new dimension to our understanding of the regulation of this key enzyme of carbon metabolism in cyanobacteria in general. In vegetative cells thioredoxin may play a key role in the light deactivation/dark activation of the oxidative pentose phosphate pathway (see Winkenbach \& Wolk, 1973; Lex \& Carr, 1974; Apte et al., 1978). In the light photosynthetically produced reductant may serve to sustain a supply of reduced thioredoxin resulting in deactivation of G6PDH and thus of the oxidative pentose phosphate pathway. In the dark, when light-generated reductant would not be available and thioredoxin would not be so reduced, G6PDH would be activated and the oxidative pentose phosphate pathway would function. Activation could also involve glucose 6-phosphate (see Figs 1 and 2) derived from fixed carbon reserves such as glycogen.

In heterocysts, unlike vegetative cells, G6PDH is active in both the light and dark (Winkenbach \& Wolk, 1973; Lex \& Carr, 1974; Apte et al., 1978). Our data suggest two possible reasons for this, neither of which is mutually exclusive. First, there may be insufficient reduced 
thioredoxin available in heterocysts to inactivate G6PDH in the light, either because of a lack in heterocysts of a functional thioredoxin/thioredoxin reductase system or because in the light, when photosynthetically generated ATP becomes available both for nitrogenase and glutamine synthetase, there is a diversion of reductant to these enzymes of nitrogen metabolism at the expense of thioredoxin. Schmidt \& Christen (1979) have reported higher thioredoxin levels in a heterocystous cyanobacterium grown on $\mathrm{N}_{2}$ when compared with $\mathrm{NO}_{3}^{-}$-grown filaments which may indicate that thioredoxin is present in heterocysts. Second, we have shown that the effects of glucose 6-phosphate, glutamine, NADP ${ }^{+}$and reduced thioredoxin on G6PDH cannot be viewed in isolation, with $\mathrm{NADP}^{+}$and reduced thioredoxin promoting deactivation of the enzyme whereas glucose 6-phosphate and glutamine prevented deactivation and, under certain conditions, promoted reactivation. It is possible that, in heterocysts, glutamine, which is probably the form in which fixed nitrogen is transported from heterocysts (Thomas et al., 1977), accumulates in quantity and, together with glucose 6-phosphate, provided directly or indirectly from vegetative cells, serves to override the deactivating effect of reduced thioredoxin.

This work was supported by the Science and Engineering Research Council. We thank S. M. Ip for providing purified thioredoxin.

\section{REFERENCES}

Allen, M. B. \& ARnon, D. I. (1955). Studies on nitrogen-fixing blue-green algae. I. Growth and nitrogen fixation by Anabaena cylindrica Lemm. Plant Physiology 30, 366-372.

Anderson, L. E., Nehrlich, S. C. \& Champigny, M. (1978). Light modulation of enzyme activity. Plant Physiology 61, 601-605.

Apte, S. K., Rowell, P. \& Stewart, W. D. P. (1978). Electron donation to ferredoxin in heterocysts of the $\mathrm{N}_{2}$-fixing alga Anabaena cylindrica. Proceedings of the Royal Society B200, 1-25.

Ashton, A. R., Brennan, T. \& Anderson, L. E. (1980). Thioredoxin-like activity of thylakoid membranes. Plant Physiology 66, 605-608.

Buchanan, B. B., Wolosiuk, R. A. \& SchürmanN, P. (1979). Thioredoxin and enzyme regulation. Trends in Biochemical Sciences 4, 93-96.

Czeke, C., Balogh, A. \& Farkas, G. L. (1981). Redox modulation of glucose-6-phosphate dehydrogenase in Anacystis nidulans and its 'uncoupling' by phage infection. FEBS Letters 126, 85-88.

DAVIS, B. J. (1964). Disc electrophoresis. II. Method and application to human serum proteins. Annals of the New York Academy of Sciences 121, 404-427.

Duggan, J. X. \& ANDerson, L. E. (1975). Light regulation of enzyme activity in Anacystis nidulans (Richt.). Planta 122, 293-297.

Grossman, A. \& McGowan, R. E. (1975). Regulation of glucose-6-phosphate dehydrogenase in blue-green algae. Plant Physiology 55, 658-662.

HedRick, J. L. \& SMith, A. J. (1968). Size and charge isomer separation and estimation of molecular weights of proteins by disc gel electrophoresis. Archives of Biochemistry and Biophysics 126, 155164.

Holmgren, A. (1976). Hydrogen donor system for Escherichia coli ribonucleoside-diphosphate reductase dependent upon glutathione. Proceedings of the National Academy of Sciences of the United States of America 73, 2275-2279.

Igaue, I., Tamura, H., Endo, K. \& Satto, K. (1981). Aggregated forms of glucose-6-phosphate dehydro- genase (EC 1.1.1.49) from cultured rice plant cells. Plant Cell Physiology 22, 311-316.

LAEMMLI, U. K. (1970). Cleavage of structural proteins during the assembly of the head of bacteriophage $T_{4}$. Nature, London 227, 680-685.

Lara, C., DE la Torre, A. \& Buchanan, B. B. (1980). A new protein factor functional in the ferredoxinindependent light activation of chloroplast fructose1,6-bisphosphatase. Biochemical and Biophysical Research Communications 93, 544-551.

LEVY, H. R. (1979). Glucose-6-phosphate dehydrogenase. Advances in Enzymology 48, 97-192.

LEX, M. \& CARR, N. G. (1974). The metabolism of glucose by heterocysts and vegetative cells of Anabaena cylindrica. Archives of Microbiology 101, 161-167.

MEJBAum-KATZenellenboger, W. \& DOBRyszyCKa, W. (1959). New method for quantitative determination of serum proteins separated by paper electrophoresis. Clinica chimica acta 4, 515-522.

Mohammed, A. H. \& ANDerson, L. E. (1981). Extraction of chloroplast light effect mediator(s) and reconstitution of light activation of NADP-linked malate-dehydrogenase. Archives of Biochemistry and Biophysics 209, 606-612.

Pelroy, R. A. \& Bassham, J. A. (1972). Photosynthetic and dark carbon metabolism in unicellular bluegreen algae. Archiv für Mikrobiologie 86, 25-38.

Pelroy, R. A., RipPKa, R. \& Stanier, R. Y. (1972). The metabolism of glucose by unicellular blue-green algae. Archiv für Mikrobiologie 87, 303-322.

Pelroy, R. A., Kirk, M. R. \& Bassham, J. A. (1976). Photosystem II regulation of macromolecule synthesis in the blue-green alga Aphanocapsa 6714. Journal of Bacteriology 128, 623-632.

Raboy, B., Padan, E. \& Shilo, M. (1976). Heterotrophic capacities of Plectonema boryanum. Archives of Microbiology 110, 77-85.

SChaeffer, F. \& STANieR, R. Y. (1978). Glucose-6phosphate dehydrogenase of Anabaena sp. Kinetics and molecular properties. Archives of Microbiology 116, 9-19. 
SCHEIBE, R. \& ANDERSON, L. E. (1981). Dark modulation of NADP-dependent malate dehydrogenase and glucose-6-phosphate dehydrogenase in the chloroplast. Biochimica et biophysica acta 636, 5864.

SCHMidT, A. \& Christen, U. (1979). Distribution of thioredoxins in cyanobacteria. Zeitschrift für Naturforschung 34C, 1272-1274.

Smith, A. (1982). Modes of cyanobacterial carbon metabolism. In The Biology of Cyanobacteria, pp. 47 85. Edited by N. G. Carr \& B. A. Whitton. Oxford: Blackwell Scientific Publications.

Stewart, W. D. P. (1980). Some aspects of structure and function in $\mathrm{N}_{2}$-fixing cyanobacteria. Annual Review of Microbiology 34, 497-536.

Thomas, J., Meeks, J. C., Wolk, C. P., Shaffer, P. W., Austin, S. M. \& Chien, W.-S. (1977). Formation of glutamine from ${ }^{13} \mathrm{~N}$ ammonia, ${ }^{13} \mathrm{~N}$ dinitrogen, and ${ }^{14} \mathrm{C}$ glutamate by heterocysts isolated from Anabaena cylindrica. Journal of Bacteriology 129, 1545-1555.

de la Torre, A., Lara, C., Yee, B. C., Malkin, R. \& Buchanan, B. B. (1982). Physiochemical properties of ferralterin, a regulatory iron-sulfur protein functional in oxygenic photosynthesis. Archives of Biochemistry and Biophysics 213, 545-550.

Tsang, M. L. (1981). Thioredoxin/glutaredoxin system of Chlorella. Plant Physiology 68, 1098-1104.

Udvardy, J., Juhaz, A. \& Farkas, G. L. (1983). Interaction between hysteretic regulation and redox modulation of glucose-6-phosphate dehydrogenase from Anacystis nidulans. FEBS Letters 152, 97-100.

WILDNER, G. F. (1975). The regulation of glucose-6phosphate dehydrogenase in chloroplasts. Zeitschrift für Naturforschung 30C, 756-760.

Winkenbach, F. \& Wolk, C. P. (1973). Activities of enzymes of the oxidative and the reductive pentose phosphate pathways in heterocysts of a blue-green alga. Plant Physiology 52, 480-483.

Wolosiuk, R. A., Schurmann, P. \& Buchanan, B. B (1980). Thioredoxin and ferredoxin-thioredoxin reductase of spinach chloroplasts. Methods in Enzymo$\log y$ 69, 382-391.

Yee, B. C., de la Torre, A., Crawford, N. A., Lara, C., Carlson, D. E. \& Buchanan, B. B. (1981). The ferredoxin-thioredoxin system of enzyme regulation in a cyanobacterium (Nostoc muscorum). Archives of Microbiology 130, 14-18. 